\title{
Study of Heat and Mass Transfer Through an Earth to Air Heat Exchanger Equipped with Fan in South West of Algeria
}

\author{
Nasreddine Sakhri ${ }^{*}$, Younes Menni ${ }^{2}$, Ali J. Chamkha ${ }^{3}$, Giulio Lorenzini ${ }^{4}$, Noureddine Kaid ${ }^{1,5}$, Houari Ameur ${ }^{5}$, Mohammed \\ Bensafi $^{1}$ \\ ${ }^{1}$ Laboratory of Energy in Arid Areas (ENERGARID), University of Bechar, B.P. 417, 08000, Bechar, Algeria \\ ${ }^{2}$ Unit of Research on Materials and Renewable Energies, Department of Physics, Faculty of Sciences, Abou Bekr Belkaid \\ University, B.P. 119, 13000, Tlemcen, Algeria \\ ${ }^{3}$ Mechanical Engineering Department, Prince Sultan Endowment for Energy and Environment, Prince Mohammad Bin Fahd \\ University, Al-Khobar 31952, Saudi Arabia \\ ${ }^{4}$ Department of Engineering and Architecture, University of Parma, Parco Area Delle Scienze 181/A, 43124 Parma, Italy \\ ${ }^{5}$ Department of Technology, University Center Salhi Ahmed of Naâma (Ctr Univ Naâma), B.P. 66, 45000, Naâma, Algeria
}

Corresponding Author Email: sakhrinasreddine@gmail.com

https://doi.org/10.18280/ijht.370304

Received: 1 June 2019

Accepted: 22 July 2019

\section{Keywords:}

earth to air heat exchanger, arid region, underground temperature, relative humidity

\begin{abstract}
Earth to air heat exchanger is a very old technique used 3000 years B.C in arid regions where that was called Qanat. In the present experimental study, the potentials of earth to air heat exchanger to provide thermal comfort for winter weather conditions in South west of Algeria described as arid region are investigated. An EAHE made of 66 meter of PVC tube and buried at 1.5 meter underground in agriculture zone equipped with $33 \mathrm{~W}$ fan was studied. Thermal and hygrometric analysis of air passing inside the tube form inlet to outlet was conducted. The results show the system was able to create two thermal regimes: heating regime with a gain of $13{ }^{\circ} \mathrm{C}$ (from $00 \mathrm{~h}$ to $11 \mathrm{~h}$ and from $17 \mathrm{~h}$ to $23 \mathrm{~h}$ ) and cooling regime (from $12 \mathrm{~h}$ to $16 \mathrm{~h}$ ) with $6{ }^{\circ} \mathrm{C}$ in the same day. Relative humidity was reduced by $32 \%$ of $90 \%$ of studied cases which stops the development of micro-organism and reducing Internal Air Quality.
\end{abstract}

\section{INTRODUCTION}

Heat exchangers used in several sectors and in very diverse fields that require the fluid heat transfer. Gómez et al. [1] presented a CFD tool, implemented in Open FOAM and executed in a Cloud environment, to simulate the performance of shell and tube heat exchangers. Agbossou et al. [2] proposed 3D finite element modelling of helical coil ground heat exchangers focusing on the real geometry of the heat exchanger and the energy extracted from the ground. Alimonti et al. [3] analyzed the available literature on the wellbore heat exchangers. Bahiraei et al. [4] reviewed and summarized recent investigations conducted on use of nanofluids in heat exchangers including those carried out on plate heat exchangers, double-pipe heat exchangers, shell and tube heat exchangers, and compact heat exchangers. Bone et al. [5] presented a methodology to develop accurate and computationally efficient on- and off-design models of heat exchangers that exhibit complex nonlinear behaviours. Chen et al. [6] developed a novel method combined signal flow graph of a single heat exchanger with the transfer function of streams for the dynamic behaviors of heat exchanger networks problems, which are determinate factors of the process control and operation optimization in the processing industries. Estrada et al. [7] reported the design of earth-air heat exchangers based not only on sensible heat transfer, but also on latent heat exchanges. They compare the impact of the climate of Brazil and south of France on the relevance of such systems. Gao et al. [8] reviewed the latest research on ground heat exchangers from several new perspectives and demonstrated their potentials in achieving zero energy buildings. Gu et al. [9] numerically studied the heat transfer coefficient, flow resistance and thermal performance in the shell side. Ilori et al. [10] investigated the thermal and pressure drop performance of compact tube heat exchanger under oscillatory flow conditions using experimental and numerical methods. Jiang et al. [11] proposed a new methodology for heat exchanger network retrofit to fully evaluate the performance of a heat exchanger network. Kayabasi and Kurt [12] derived relations between effectiveness and expense coefficients. They prepared an economic simulation model to simulate the heat exchangers in all flow types and monitor the savings in a facility. Laukkanen and Seppälä [13] studied the effect of using nanofluids in streams transferring heat from different processes by optimizing the total annual cost of a heat exchanger network. Majuri et al. [14] examined the types and construction practices of ground heat exchangers (GHEs) in the northern conditions typical of Finland, as well as the range of problems in GHEs experienced by the practitioners. Muszynski [15] described the comprehensive study on the effect of microjet array geometrical parameters on the heat transfer enhancement in the modular heat exchanger.

Belaid and Hireche [16] carried out a numerical study to assess the effect of heat exchangers plates inter-spacing on the performance of a thermoacoustic refrigerator. Piotrowska and Skowronski [17] performed an analysis of temperature oscillation parameters in transient states of heat exchange systems through an investigation carried out using a measuring stand with a heat exchanger model. Song et al. [18] 
used the graphite modified poly (vinylidene fluoride) hollow fibers as the heat transfer medium to investigate the heat transfer processes including liquid-liquid, condensation and evaporation systems. Sun et al. [19] presented two system configurations of the enhanced ejector heat exchanger to improve the regulating characteristics and the heat transfer performance. Whalley and Ebrahimi [20] considered the modelling and dynamic analysis of shell and tube heat exchangers in their contribution. $\mathrm{Wu}$ et al. [21] experimentally investigated the feasibility of an expandedgraphite paraffin phase change material heat exchanger operating as a condenser in an instant air source heat pump water heater. Xia et al. [22] analyzed the heat exchanger network synthesis problem based on entransy theory. Zhang et al. [23] demonstrated the successful fabrication of a gas-togas manifold-microchannel heat exchanger through DMLS (direct metal laser sintering) using Inconel 718. They experimentally tested the heat exchanger with $\mathrm{N} 2$ on the hotside at $600{ }^{\circ} \mathrm{C}$ and air on the cold-side at $38{ }^{\circ} \mathrm{C}$. Other studies can be found in the literature as Menni et al. [24-43].

In the present experimental study, the potentials of earth to air heat exchanger to provide thermal comfort for winter weather conditions in South west of Algeria described as arid region are investigated.

\section{EAHE UNDER EXPERIMENTATION}

For the present study, an earth to air heat exchanger (EAHE) was made of 66 meters PVC tube with a diameter of $110 \mathrm{~mm}$ and buried at $150 \mathrm{~cm}$ underground in agriculture zone. The system was equipped with a fan at the inlet (33 Watt) where external air was injected at $3 \mathrm{~m} / \mathrm{s}$. Temperature and relative humidity sensors were installed at EAHE inlet and outlet, see Figure 1.

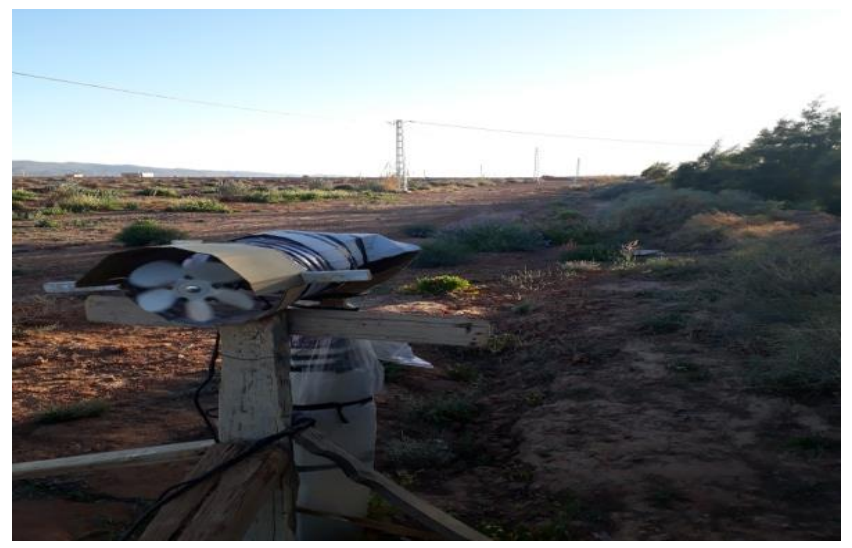

Figure 1. Earth to air heat exchanger inlet and outlet

\section{RESULTS AND DISCUSSIONS}

The experimental study was conducted between December 2018 and February 2019. For outside, the temperature was situated between $-1{ }^{\circ} \mathrm{C}$ for the lowest and $27{ }^{\circ} \mathrm{C}$ for the highest. In the same time, $12.2{ }^{\circ} \mathrm{C}$ was the lowest temperature value for EAHE outlet and the highest was $22.5^{\circ} \mathrm{C}$. Even with outside temperature was $(-1){ }^{\circ} \mathrm{C}$, EAHE rise this negative temperature to $12.2{ }^{\circ} \mathrm{C}$ by approximately $13.2{ }^{\circ} \mathrm{C}$ which reduce at least half of heating needs for this cold climate.
Earth to air heat exchanger work as thermal regulator of air passing through the buried tube. The difference between the highest and lowest value of temperature was $20.15{ }^{\circ} \mathrm{C}$ for inlet while it was $7.5^{\circ} \mathrm{C}$ for EAHE outlet, see Figure 2. This results show the capacity of the technique equipped of exterior fan of reducing the range of temperature variation and to give more stability of the system even with sever climate conditions in comparison to system without fan studied before depended greatly to local weather conditions.

For relative humidity, it was situated between 13 and $59 \%$ for EAHE inlet and 15 to $31 \%$ for the outlet, see Figure 3.

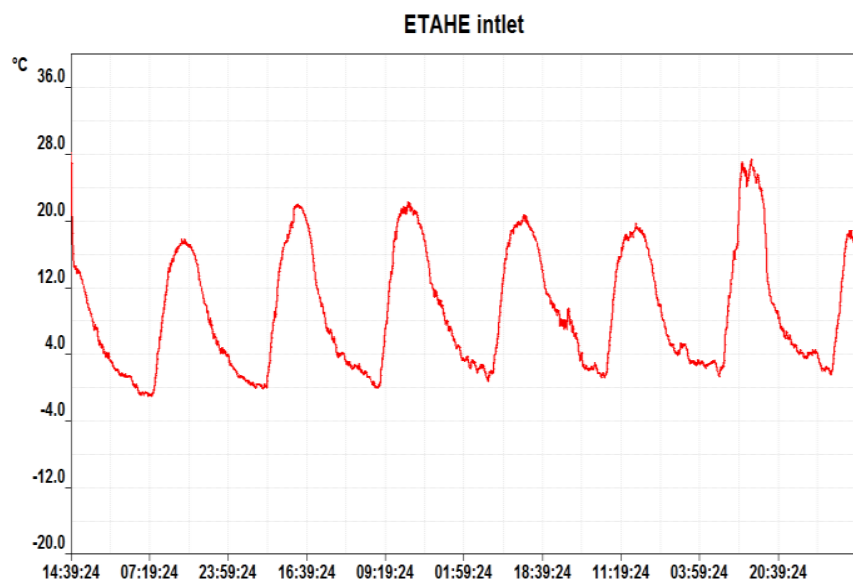

(a)

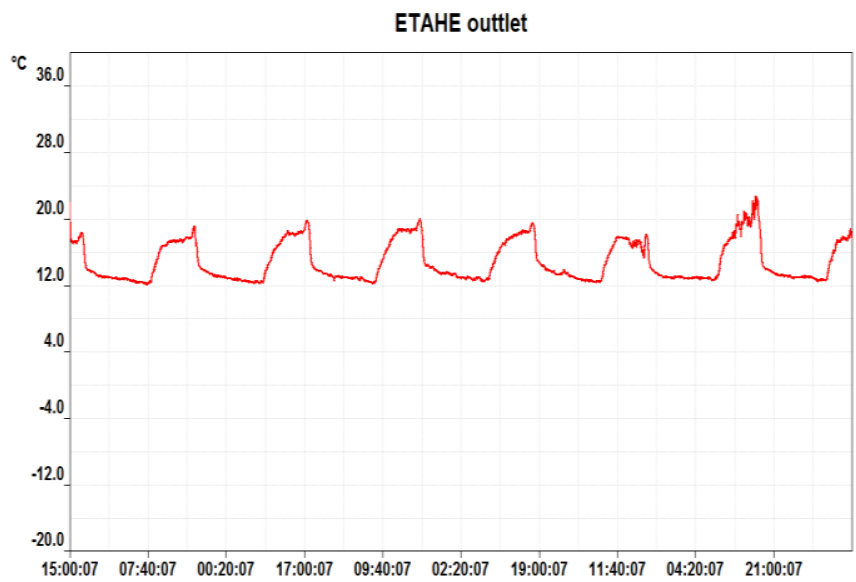

(b)

Figure 2. Earth to air heat exchanger (a) inlet and (b) outlet

To show the earth to air heat exchanger thermal and hygrometric capacities, $\Delta \mathrm{T}=\mathrm{T}_{\text {inlet }}-\mathrm{T}_{\text {outlet }}$ and $\Delta \mathrm{RH}=\mathrm{RH}_{\text {inlet }}$ - $\mathrm{RH}_{\text {outlet }}$ are calculated, as shown in Figures 4 and 5, respectively.

For thermal regime, hourly and daily mean temperature differences are also calculated. It was observed that $80 \%$ of the values were negatives which means that $\mathrm{T}_{\text {inlet }}<\mathrm{T}_{\text {outlet }}$ and only $20 \%$ of the differences were positives $\left(\mathrm{T}_{\text {inlet }}<\mathrm{T}_{\text {outlet }}\right)$, see Figure 6. Generally, $\mathrm{T}_{\text {inlet }}<\mathrm{T}_{\text {outlet }}$ means that the system rises the air temperature during its passage through the buried PVC tube to create a heating regime. It was observed also that the heating regime took place between $00 \mathrm{~h}$ to $11 \mathrm{~h}$ and $17 \mathrm{~h}$ to $23 \mathrm{~h}$. In this period, outside air temperature is very low and EAHE contribute in increasing it where the gain reaches between 4 to $13{ }^{\circ} \mathrm{C}$. This results leads to an ameliorated heating regime and a big adaptation of the system to local climate conditions. 
For hygrometrique regime, hourly and daily mean relative humidity difference between the system inlet and outlet was positive $\mathrm{RH}_{\text {inlet }}>\mathrm{RH}_{\text {outlet, }}$, see Figure 7.

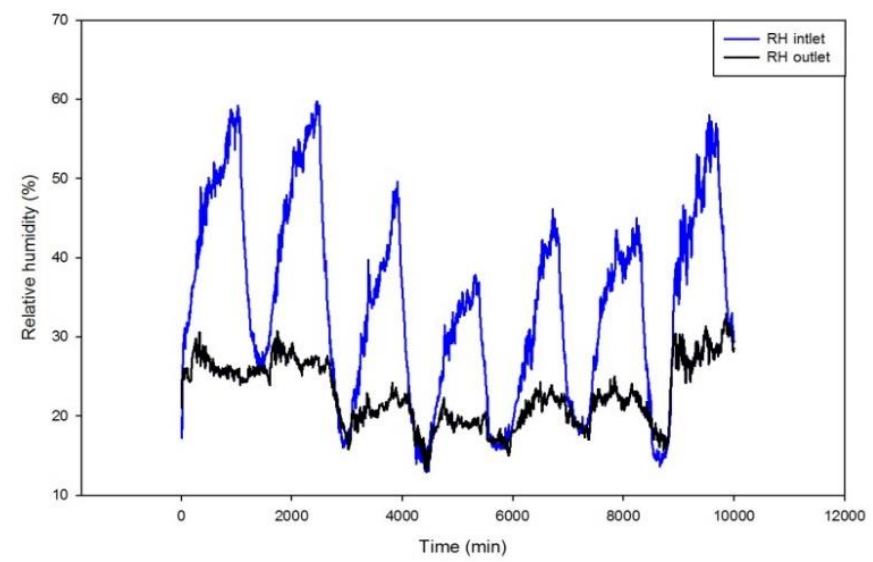

Figure 3. EAHE inlet and outlet relative humidity (\%)

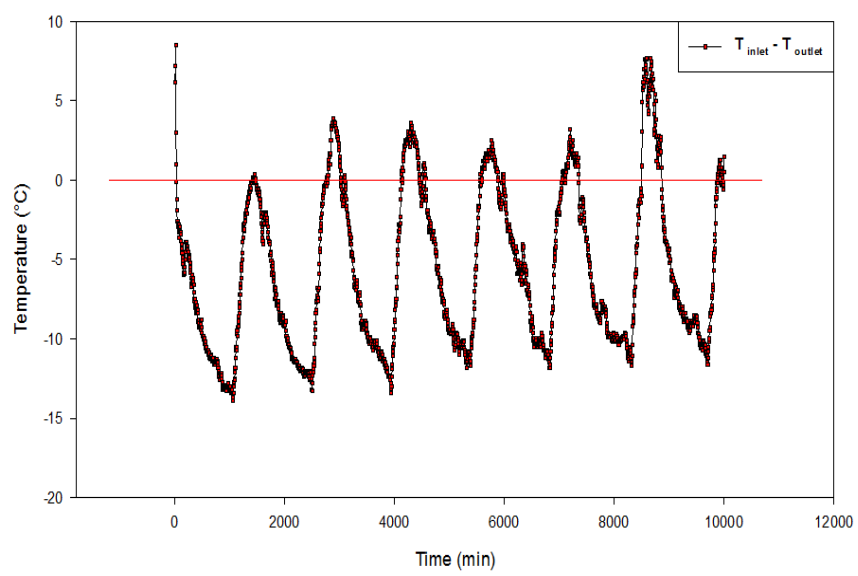

Figure 4. Air temperature difference between inlet and outlet

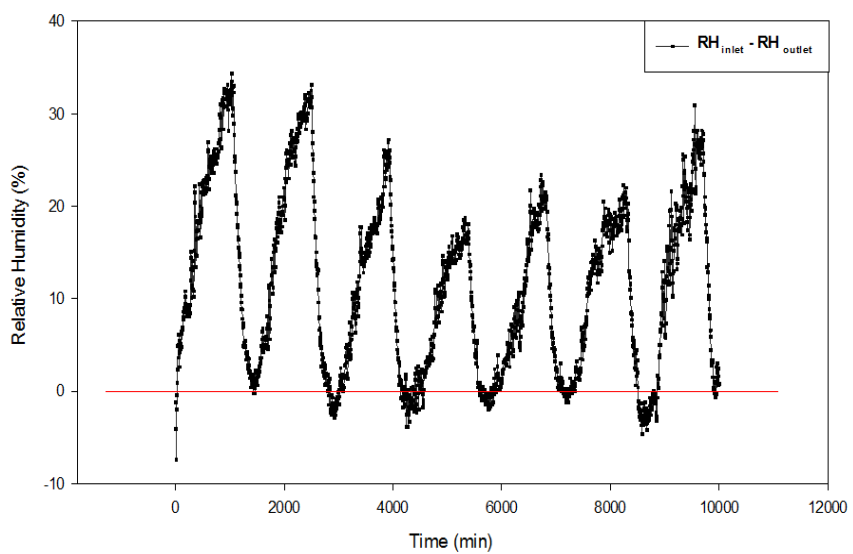

Figure 5. Air relative humidity difference

A dehumidification process occurs when fan is running which leads to decrease the relative humidity with maximum value of $32 \%$ between $5 \mathrm{~h}$ to $8 \mathrm{~h}$ in the morning. The fan with velocity of $3 \mathrm{~m} / \mathrm{s}$ plays dehumidification roles reducing condensation phenomena inside the tube. Condensation phenomena sometimes can develop micro-organisms which reduce internal air quality IAQ and the ad of the fan at the inlet of the system can reduce these effects to improve occupant's health and comfort. Analysis of dew points of both inlet and outlet show that it was between -2 to $-12{ }^{\circ} \mathrm{C}$. DPoutelt was lower in comparison with those for of the inlet. These results confirm the role played by the fan for improving IAQ and thermal comfort, see Figure 8.

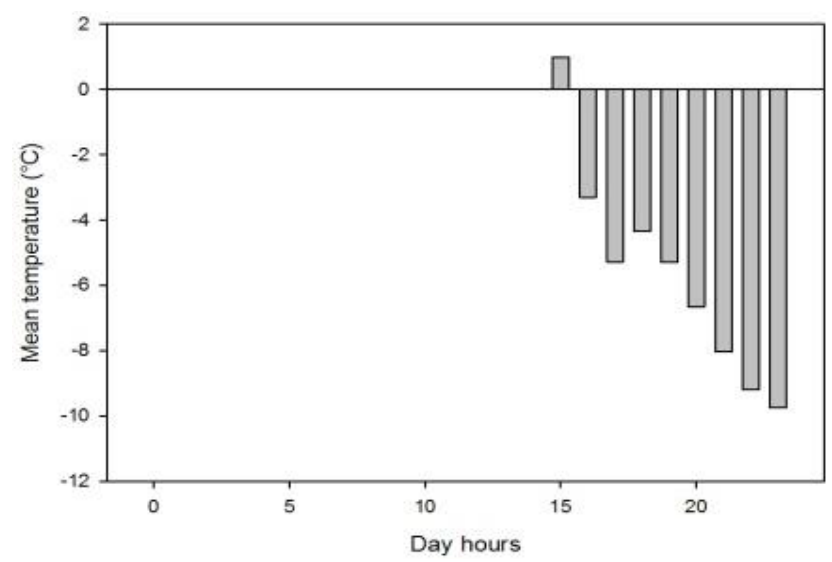

(a) Day 1

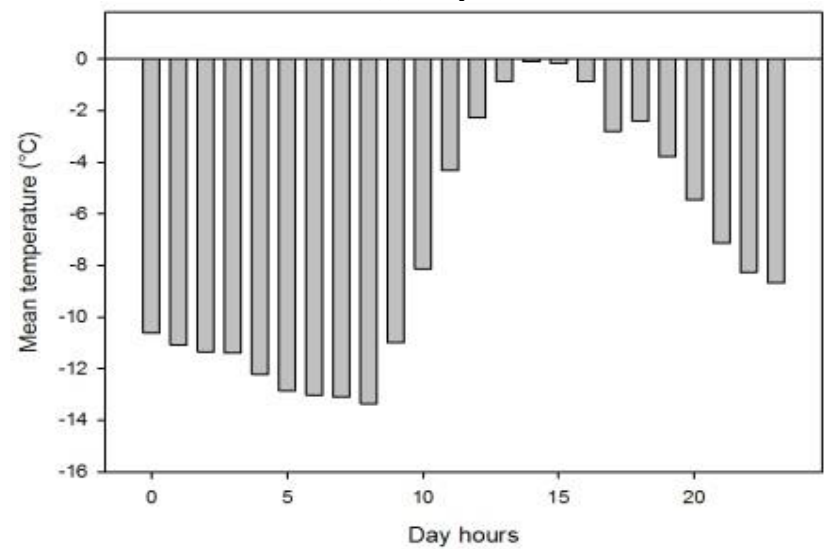

(b) Day 2

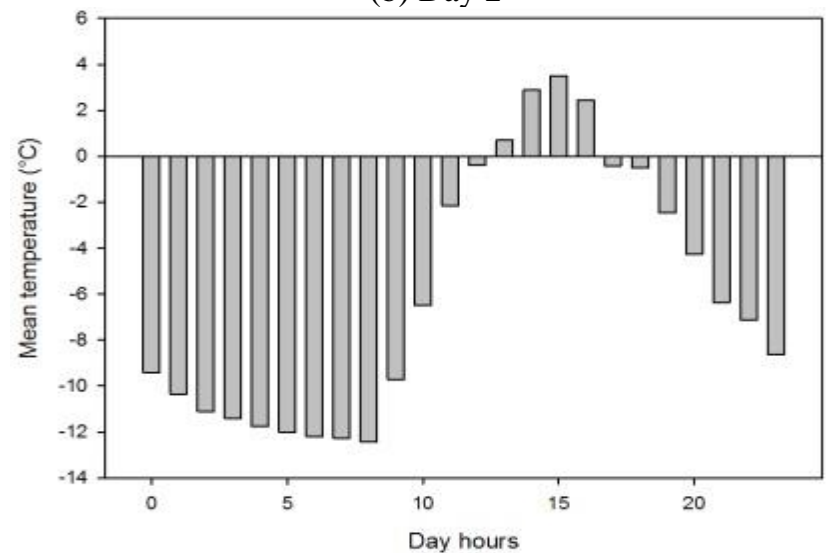

(c) Day 3

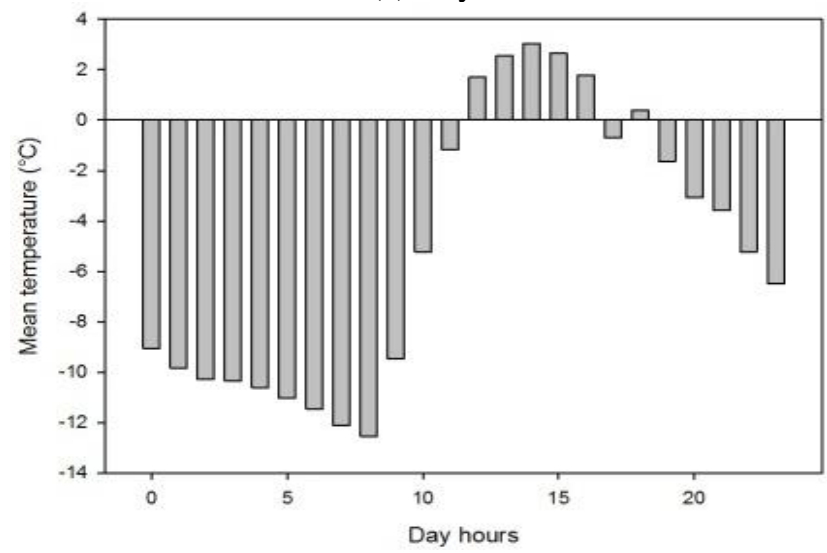

(d) Day 4 


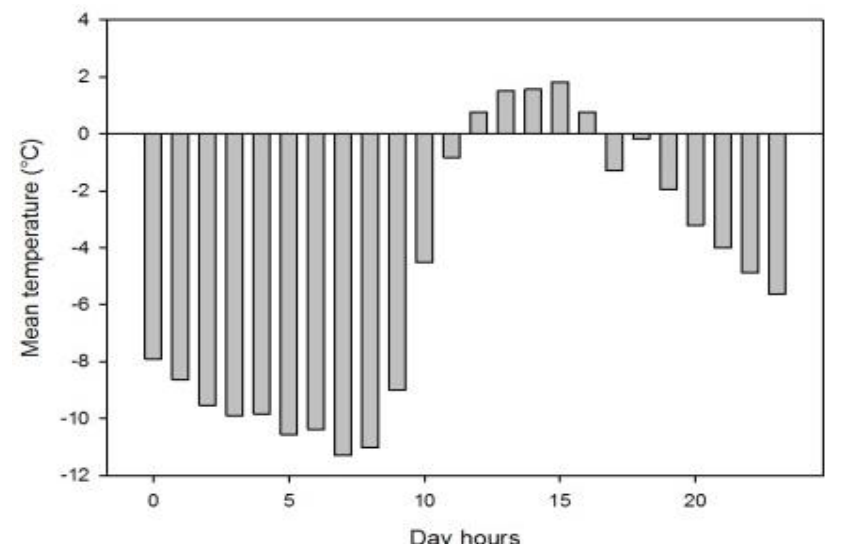

(e) Day 5

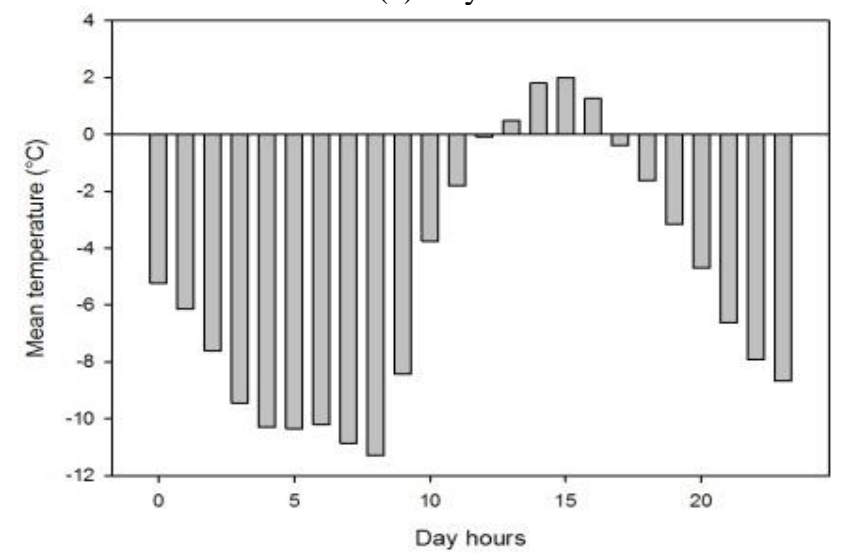

(f) Day 6

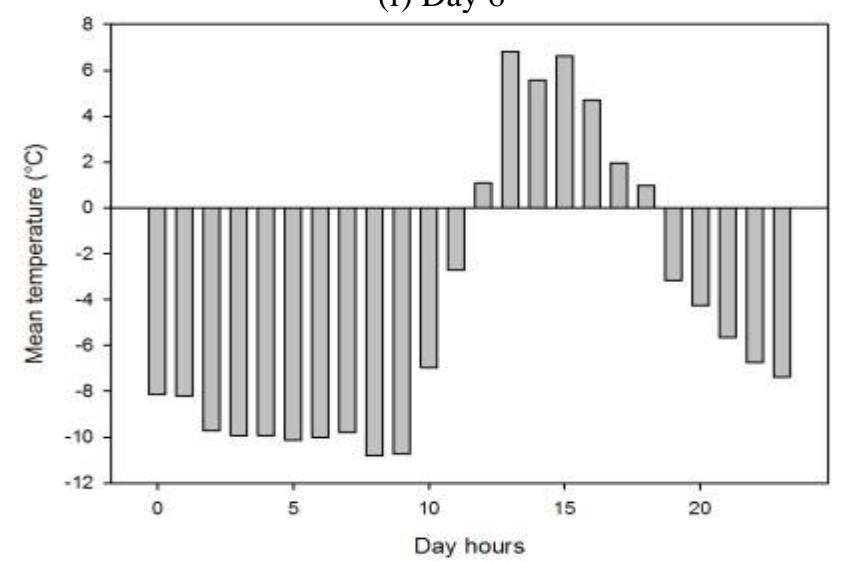

(g) Day 7

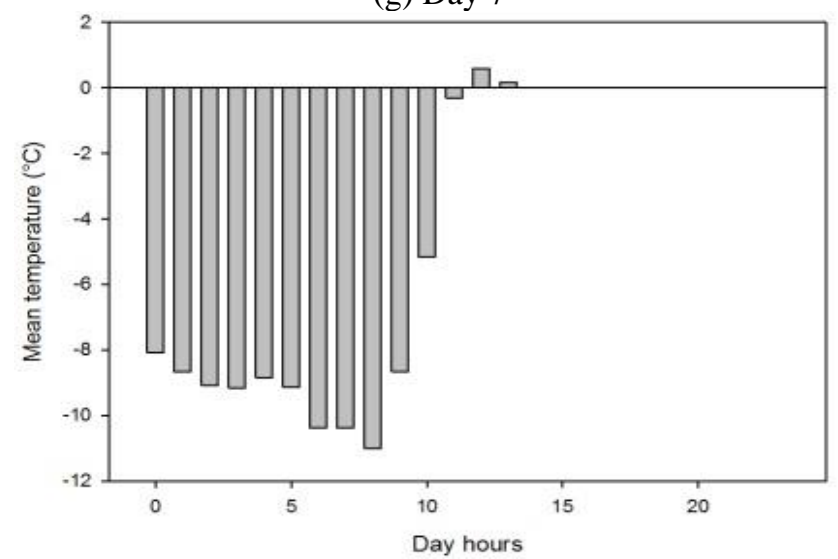

(h) Day 8

Figure 6. Hourly and daily temperature difference between inlet and outlet

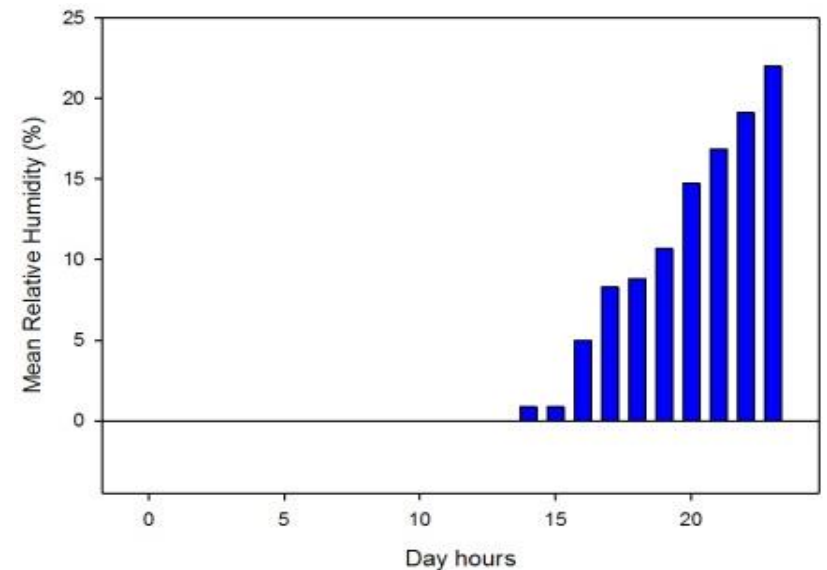

(a) Day 1

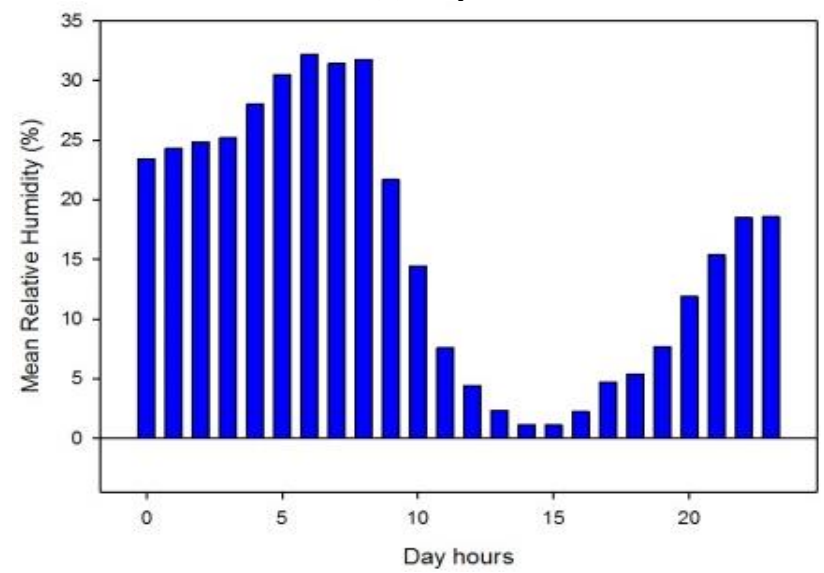

(b) Day 2

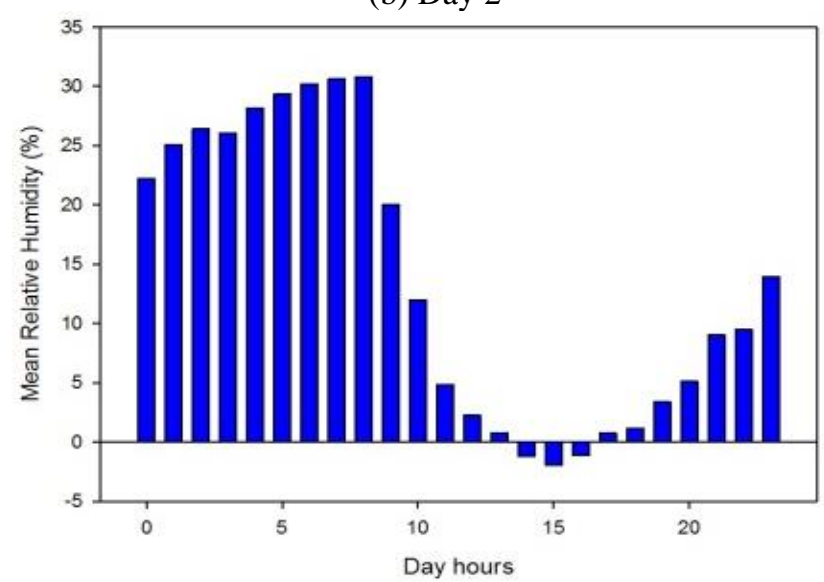

(c) Day 3

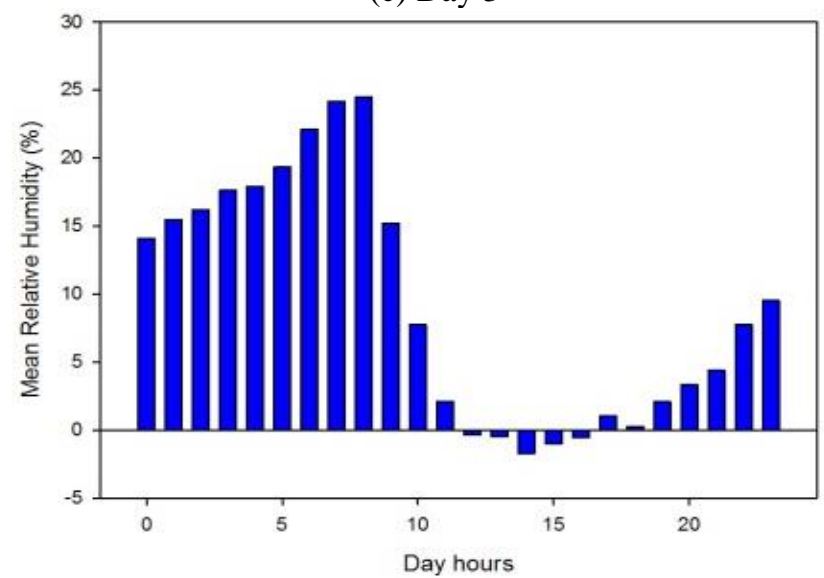

(d) Day 4 


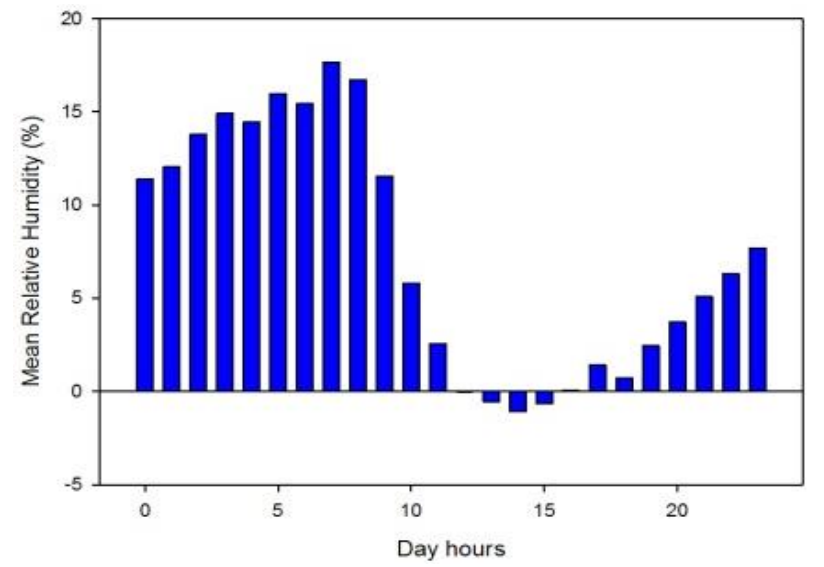

(e) Day 5

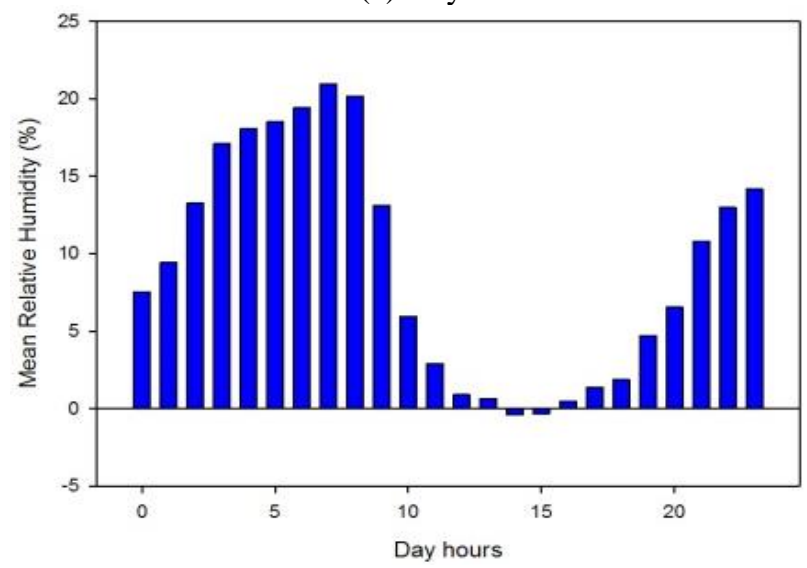

(f) Day 6

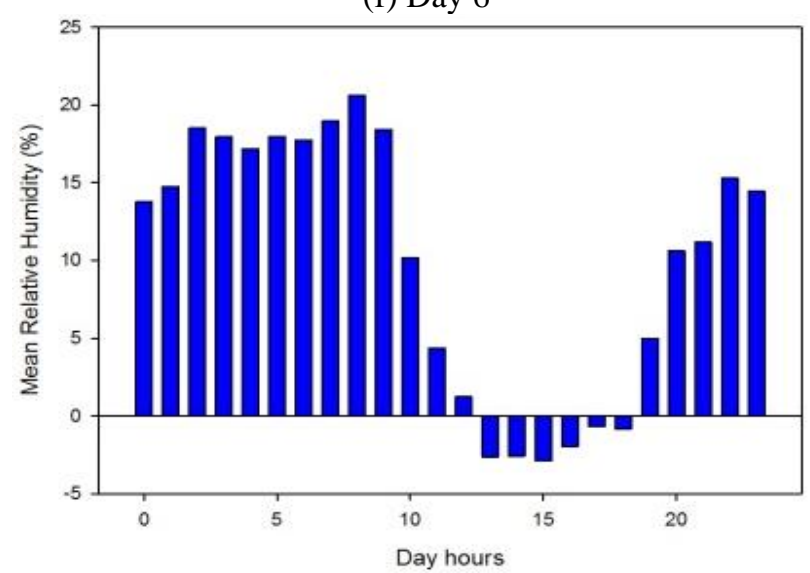

(g) Day 7

Figure 7. Hourly and daily RH $\Delta$ between inlet and outlet

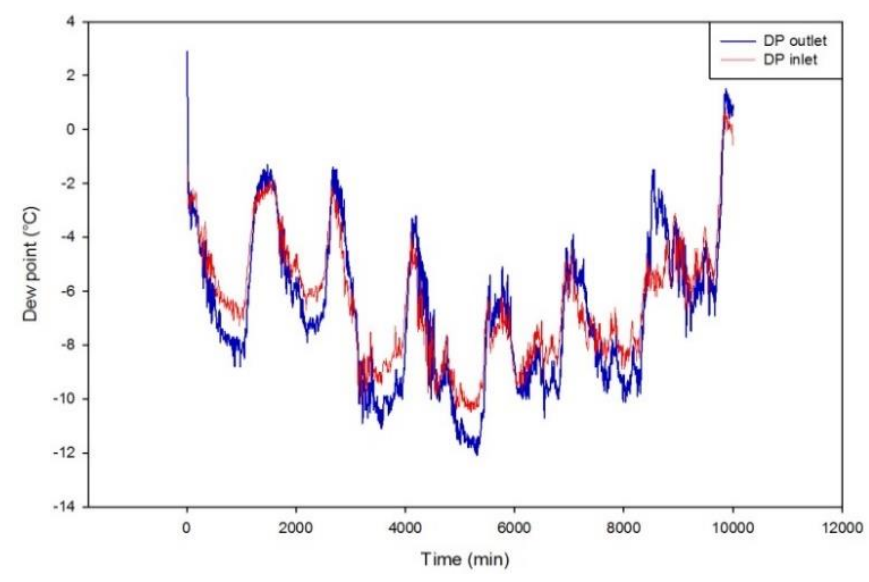

Figure 8. Earth to air heat exchanger inlet and outlet dew point

\section{CONCLUSION}

EAHE is a very old technique used in Persia 3000 years B.C and it was called Qanat and used to provide thermal comfort in arid regions. In the present study, an EAHE made of 66 meters of PVC tube buried at $1.5 \mathrm{~m}$ underground in the south west of Algeria was investigated experimentally. Heat and mass transfer occurring inside tube were analysed.

The results show that earth to air heat exchanger work as a thermal regulator of air passing through the buried pipe under 1.5 meter of the ground surface. Thermal regulation of EAHE was clearly observed by reducing the range of temperature variation between inlet (from $20^{\circ} \mathrm{C}$ ) and outlet (at $8{ }^{\circ} \mathrm{C}$ ).

Instability in outlet air temperature is one of the advantages of this technique. By using the present studied configuration, instabilities are reduced to maximum and prediction of outlet temperature become easier.

It was also observed the big dependence of the EAHE with external tube to local climate conditions and the same time the big adaptation of this technique to those variations and this led to the creation of two thermal regimes as follow:

Heating regime: from $00 \mathrm{~h}$ to $11 \mathrm{~h}$ and from $17 \mathrm{~h}$ to $23 \mathrm{~h}$ where exterior air temperature was very low and during its passage inside the tube, the air gain $13{ }^{\circ} \mathrm{C}$ where ground work as a heating source. Cooling regime: from $12 \mathrm{~h}$ to $16 \mathrm{~h}$ where ground work as a heat sink reducing air temperature at EAHE outlet by more than $6{ }^{\circ} \mathrm{C}$.

These two regimes improve thermal comfort in arid regions with different climate conditions.

Hygrometrique regime was characterized by a reduction in relative humidity in $90 \%$ of the cases by $32 \%$ and $10 \%$ of cases where $\mathrm{RH}$ rise by $3 \%$. Those results have advantage and disadvantage.

The advantage is the elimination of condensation phenomena where dew point was situated between -2 and $12{ }^{\circ} \mathrm{C}$. Condensation inside buried tube may develop microorganisms and reduce internal air quality IAQ.

Disadvantage of relative humidity reduction is internal hygrometrique comfort is directly affected where $\mathrm{RH}$ must be at least $50 \%$. This situation can be corrected by introducing a humidification mechanism at the outlet of EAHE connected directly to living space.

Great potentials are presented by earth to air heat exchanger in arid regions for thermal comfort and natural ventilation.

\section{REFERENCES}

[1] Gómez, A., Montañés, C., Cámara, M., Cubero, A., Fueyo, N., Muñoz, J.M. (2018). An open FOAM-based model for heat-exchanger design in the cloud. Applied Thermal Engineering, 139: 239-255. https://doi.org/10.1016/j.applthermaleng.2018.04.093

[2] Agbossou, A., Souyri, B., Stutz, B. (2018). Modelling of helical coil heat exchangers for heat pump applications: analysis of operating modes and distance between heat exchangers. Applied Thermal Engineering, 129: $1068-1078$ https://doi.org/10.1016/j.applthermaleng.2017.10.089

[3] Alimonti, C., Soldo, E., Bocchetti, D., Berardi, D. (2018). The wellbore heat exchangers: A technical review. Renewable Energy, 123: 353-381. https://doi.org/10.1016/j.renene.2018.02.055 
[4] Bahiraei, M., Rahmani, R., Yaghoobi, A., Khodabandeh E., Mashayekhi, R., Amani, M. (2018). Recent research contributions concerning use of nanofluids in heat exchangers: A critical review. Applied Thermal Engineering, 133: 137-159. https://doi.org/10.1016/j.applthermaleng.2018.01.041

[5] Bone, V., McNaughton, R., Kearney, M., Jahn, I. (2018). Methodology to develop off-design models of heat exchangers with non-ideal fluids. Applied Thermal Engineering, 145: 716-734. https://doi.org/10.1016/j.applthermaleng.2018.09.082

[6] Chen, J., Cui, G., Xiao, Y. (2018). An analytical solution to the dynamic behavior of heat exchanger networks. International Journal of Heat and Mass Transfer, 126: 466-478. https://doi.org/10.1016/j.ijheatmasstransfer.2018.05.041

[7] Estrada, E., Labat, M., Lorente, S., Rocha, L.A.O. (2018). The impact of latent heat exchanges on the design of earth air heat exchangers. Applied Thermal Engineering, 129: 306-317. https://doi.org/10.1016/j.applthermaleng.2017.10.007

[8] Gao, J., Li, A., Xu, X., Gang, W., Yan, T. (2018). Ground heat exchangers: Applications, technology integration and potentials for zero energy buildings. Renewable Energy, 128: 337-349. https://doi.org/10.1016/j.renene.2018.05.089

[9] Gu, X., Luo, Y., Xiong, X., Wang, K., Wang, Y. (2018). Numerical and experimental investigation of the heat exchanger with trapezoidal baffle. International Journal of Heat and Mass Transfer, 127: 598-606. https://doi.org/10.1016/j.ijheatmasstransfer.2018.07.045

[10] Ilori, O.M., Jaworski, A.J., Mao, X. (2018). Experimental and numerical investigations of thermal characteristics of heat exchangers in oscillatory flow. Applied Thermal Engineering, 144: 910-925. https://doi.org/10.1016/j.applthermaleng.2018.07.073

[11] Jiang, N., Han, W., Guo, F., Yu, H., Xu, Y., Mao, N. (2018). A novel heat exchanger network retrofit approach based on performance reassessment. Energy Conversion and Management, 177: 477-492. https://doi.org/10.1016/j.enconman.2018.10.001

[12] Kayabasi, E., Kurt, H. (2018). Simulation of heat exchangers and heat exchanger networks with an economic aspect. Engineering Science and Technology, 21(1):

70-76. https://doi.org/10.1016/j.jestch.2018.02.006

[13] Laukkanen, T., Seppälä, A. (2018). Interplant heat exchanger network synthesis using nanofluids for interplant heat exchange. Applied Thermal Engineering, 135: $133-144$. https://doi.org/10.1016/j.applthermaleng.2018.01.114

[14] Majuri, P. (2018). Technologies and environmental impacts of ground heat exchangers in Finland. Geothermics, 73: 124-132. https://doi.org/10.1016/j.geothermics.2017.08.010

[15] Muszynski, T. (2018). The influence of microjet array area ratio on heat transfer in the compact heat exchanger. Experimental Thermal and Fluid Science, 99: 336-343. https://doi.org/10.1016/j.expthermflusci.2018.08.010

[16] Belaid, K.N., Hireche, O. (2018). Influence of heat exchangers blockage ratio on the performance of thermoacoustic refrigerator. International Journal of Heat and Mass Transfer, 127: 834-842. https://doi.org/10.1016/j.ijheatmasstransfer.2018.05.144

[17] Piotrowska, E., Skowronski, P. (2018). Analysis of temperature oscillations parameters of heat exchanging systems. International Journal of Heat and Mass Transfer, 127:

651-662. https://doi.org/10.1016/j.ijheatmasstransfer.2018.07.032

[18] Song, S., Shan, H., Liu, J., Li, B. (2018). Heat transfer study of PVDF hollow fiber heat exchanger for desalination process. Desalination, 446: 1-11. https://doi.org/10.1016/j.desal.2018.08.016

[19] Sun, F., Chen, X., Fu, L., Zhang, S. (2018). Configuration optimization of an enhanced ejector heat exchanger based on an ejector refrigerator and a plate heat exchanger. Energy, 164: 408-417. https://doi.org/10.1016/j.energy.2018.08.194

[20] Whalley, R., Ebrahimi, K.M. (2018). Heat exchanger dynamic analysis. Applied Mathematical Modelling, 62: 38-50. https://doi.org/10.1016/j.apm.2018.04.024

[21] Wu, J., Feng, Y., Liu, C., Li, H. (2018). Heat transfer characteristics of an expanded graphite/paraffin PCMheat exchanger used in an instantaneous heat pump water heater. Applied Thermal Engineering, 142: 644655 . https://doi.org/10.1016/j.applthermaleng.2018.06.087

[22] Xia, L., Feng, Y., Sun, X., Xiang, S. (2018). Design of heat exchanger network based on entransy theory. Chinese Journal of Chemical Engineering, 26(8): 16921699. https://doi.org/10.1016/j.cjche.2017.10.007

[23] Zhang, X., Tiwari, R., Shooshtari, A.H., Ohadi, M.M. (2018). An additively manufactured metallic manifoldmicrochannel heat exchanger for high temperature applications. Applied Thermal Engineering, 143: 899908.

https://doi.org/10.1016/j.applthermaleng.2018.08.032

[24] Menni, Y., Azzi, A. (2018). Numerical analysis of thermal and aerodynamic fields in a channel with cascaded baffles. Periodica Polytechnica Mechanical Engineering, 62(1): 16-25. https://doi.org/10.3311/PPme.10613

[25] Menni, Y., Chamkha, A., Zidani, C., Benyoucef, B. (2019). Baffle orientation and geometry effects on turbulent heat transfer of a constant property incompressible fluid flow inside a rectangular channel. International Journal of Numerical Methods for Heat \& Fluid Flow. https://doi.org/10.1108/HFF-12-2018-0718

[26] Menni, Y., Chamkha, A.J., Azzi, A., Zidani, C., Benyoucef, B. (2019). Study of air flow around flat and arc-shaped baffles in shell-and-tube heat exchangers. Mathematical Modelling of Engineering Problems, 6(1): 77-84. https://doi.org/10.18280/mmep.060110

[27] Menni, Y., Azzi, A., Chamkha, A. (2019). Enhancement of convective heat transfer in smooth air channels with wall-mounted obstacles in the flow path. Journal of Thermal Analysis and Calorimetry, 135(4): 1951-1976. https://doi.org/10.1007/s10973-018-7268-X

[28] Menni, Y., Azzi, A., Chamkha, A. (2018). Aerodynamics and heat transfer over solid-deflectors in transverse, staggered, corrugated-upstream and corrugated-downstream patterns. Periodica Polytechnica Mechanical Engineering, 62(3): 209-217. https://doi.org/10.3311/PPme.11972

[29] Menni, Y., Azzi, A., Chamkha, A. (2018). A review of solar energy collectors: Models and applications. Journal of Applied and Computational Mechanics, 4(4): 
$375-401$

https://doi.org/10.22055/JACM.2018.25686.1286

[30] Menni, Y., Azzi, A., Chamkha, A. (2018). Turbulent heat transfer and fluid flow over complex geometry fins. Deflect and Diffusion Forum, 388: 378-393. doi:10.4028/www.scientific.net/DDF.388.378

[31] Menni, Y., Azzi, A., Chamkha, A., Harmand, S. (2018). Effect of wall-mounted V-baffle position in a turbulent flow through a channel: Analysis of best configuration for optimal heat transfer. International Journal of Numerical Methods for Heat \& Fluid Flow. https://doi.org/10.1108/HFF-06-2018-0270

[32] Menni, Y., Azzi, A., Chamkha, A., Harmand, S. (2019). Analysis of fluid dynamics and heat transfer in a rectangular duct with staggered baffles. Journal of Applied and Computational Mechanics, 5(2): 231-248. https://doi.org/10.22055/JACM.2018.26023.1305

[33] Menni, Y., Azzi, A., Chamkha, A. (2018). Optimal thermo aerodynamic performance of S-shaped baffled channels. Journal of Mechanical Engineering and Sciences, $\quad 12(3)$ : 3888-3913. https://doi.org/10.15282/jmes.12.3.2018.10.0341

[34] Menni, Y., Azzi, A., Chamkha, A. (2019). Modeling and analysis of solar air channels with attachments of different shapes. International Journal of Numerical Methods for Heat \& Fluid Flow, 29(5): 1815-1845. https://doi.org/10.1108/HFF-08-2018-0435

[35] Menni, Y., Chamkha, A., Azzi, A. (2019). Nanofluid flow in complex geometries - a review. Journal of Nanofluids, $\quad 8(5)$ : $1-25$. https://doi.org/10.1166/jon.2019.1663

[36] Menni, Y., Azzi, A., Chamkha, A. (2018). Fluid flow and heat transfer over staggered ' + ' shaped obstacles. Journal of Applied and Computational Mechanics. https://doi.org/10.22055/JAFM.2018.26277.1316

[37] Menni, Y., Chamkha, A., Lorenzini, G., Benyoucef, B. (2019). Computational fluid dynamics based numerical simulation of thermal and thermo-hydraulic performance of a solar air heater channel having various ribs on absorber plates. Mathematical Modelling of Engineering Problems, 6(2): 170-174. https://doi.org/10.18280/mmep.060203

[38] Menni, Y., Chamkha, A., Zidani, C., Benyoucef, B. (2019). Heat transfer in air flow past a bottom channel wall-attached diamond-shaped baffle - using a CFD technique. Periodica Polytechnica Mechanical Engineering, 63(2): 100-112. https://doi.org/10.3311/PPme.12490

[39] Menni, Y., Chamkha, A., Zidani, C., Benyoucef, B. (2019). Heat and nanofluid transfer through baffled channels in different outlet models. Mathematical Modelling of Engineering Problems, 6(1): 21-28. https://doi.org/10.18280/mmep.060103

[40] Menni, Y., Chamkha, A., Zidani, C., Benyoucef, B. (2019). Numerical analysis of heat and nanofluid mass transfer in a channel with detached and attached baffle plates. Mathematical Modelling of Engineering Problems, 6(1): 52-60. https://doi.org/10.18280/mmep.060107

[41] Abderrahim, A., Ghellai, N., Bouzid, Z., Menni, Y. (2019). Wind energy resource assessment in south western of Algeria. Mathematical Modelling of Engineering Problems, 6(2): 157-162. https://doi.org/10.18280/mmep.060201

[42] Merabti, S., Grioui, K., Menni, Y., Chamkha, A.J., Lorenzini, E., Sakhri, N., Ameur, H. (2019). Study of some parameters influence on a Saharian building balance sheet. Revue des Composites et des Matériaux Avancés, 29(2) 83-88. https://doi.org/10.18280/rcma.290202

[43] Bendjamaa, I., Allaoui, T., Menni, Y., Chamkha, A.J., Lorenzini, E. (2018). Study and comparison between two receivers of parabolic trough collector. Mathematical Modelling of Engineering Problems, 6(3): 385-389. https://doi.org/10.18280/mmep.060309 